\title{
PERTUMBUHAN TANAMAN KANGKUNG (Ipomeaguatice Forsk) SEBAGAI INDIKATOR TINGKAT PENCEMARAN AIR SUNGAI
}

\author{
ANIKE KASTELLA \\ Universitas Pendidikan Muhammadiyah (UNIMUDA) Sorong
}

\begin{abstract}
ABSTRAK
Penelitian ini dilatar belakangi oleh tanaman kangkung bisa di jadikan indicator tingkat pencemaran air sungai.Tujuan penelitian ini adalah untuk mengetahui apakah tingkat pertumbuhan tanaman kangkung bisa dijadikan indicator tingkat pencemaran air sungai.Metode dalam penelitian ini adalah kuantitatif atau eksperimen semu.Populasi dan sampel penelitian ini adalah tanaman kangkung dan air sungai yang ada di daerah aimas. Teknik analisis data penelitian ini menggunakan uji regresi linear sederhana dan uji t. Berdasarkan perhitungan data tersebut diperoleh nilai thitung $(3,264)>$ ttabel $(3,182)$ dan $\mathrm{P}(0,005)<\alpha(0,05)$. Hasil tersebut menunjukkan bahwa nilai t hitung lebih besar dari pada ttabel dan probabilitas signifikansi kurang dari 0,05 maka Ha: diterima dan Ho: ditolak. Jika Ha diterima maka hipotesisnya berbunyi “Ada pengaruh yang signifikan terhadap tanaman kangkung sebagai indikator tingkat pencemaran air sungai.
\end{abstract}

Kata Kunci: Tanaman Kangkung, Air sungai, Pencemaran

This research is motivated by water spinach plants can be used as indicators of river water pollution levels. The purpose of this study is to determine whether the growth rate of water spinach plants can be used as an indicator of river water pollution levels. The method in this study is quantitative or quasi-experimental. Population and sample of this study are water spinach plants and river water in the aimas area. The data analysis technique of this study used a simple linear regression test and t test. Based on the calculation of the data, tcount $(3,264)>$ ttable $(3,182)$ and $P(0,005)<\alpha(0,05)$ is obtained. These results indicate that the calculated $t$ value is greater than the table and the significance probability is less than 0.05 then Ha: is accepted and Ho: is rejected. If Ha is accepted then the hypothesis reads "There is a significant effect on water spinach as an indicator of the level of river water pollution.

Keywords: Water spinach plants, river water, pollution

\section{PENDAHULUAN}

Tumbuh dan berkembang merupakan salah satu ciri makhluk hidup.pertumbuhan dan perkembangan berjalan seiring. Pertumbuhan pada tanaman terjadi karena adanya pertambahan ukuran (volume) yang Irreversible (tidak dapat balik) yang disebabkan adanya pertambahan jumlah sel melalui proses pembelahan sel secara mitosis pada titik tumbuhan dan pembesaran dari tiap-tiap sel, sedangkan perkembangan merupakan spesiallisasi sel-sel menjadi strukutr dan fungsi tertentu. Perkembangan tidak dapat dinyatakan dengan ukuran.tetapi dinyatakan dengan perubahan bentuk dan tingkat kedewasaan. Pertumbuhan dan perkembangan pada tanaman dipengaruhi oleh faktor eksternal dan faktor internal, salah satu faktor eksternal yang mempengaruhi pertumbuhan dan perkembangan tanaman adalah air. Air mutlak diperlukan tumbuhan, karena didalam hidupnya tak mungkin tumbuhan dapat tumbuh dan perkembangan tanpa memerlukan air.

Air merupakan sumber daya alam yang diperlukan untuk hajat hidup orang banyak, bahkan oleh semua makhluk hidup. Oleh karena itu sumber daya air tersebut harus dilindungi agar tetap dapat dimanfaatkan dengan baik oleh manusia dan makhluk hidup lainya. Pemanfaat air untuk berbagai kepentingan harus dilakukan secara bijaksana dengan memperhitungkan kepentingan generasi sekarang dan generasi mendatang (Nugroho,2008),

Salah satu sumber air yang banyak dimanfaatkan untuk memenuhi kebutuhan hidup manusia dan makhluk hidup lainya yaitu sungai. Sungai merupakan ekosistem yang sangat penting sebagai manusia. Sungai juga menyediakan air bagi manusia baik untuk berbagai kegiatan seperti pertanian, industri maupun domestik (siahaan dkk, 2011). Air sungai yang keluar dari mata air biasanya mempunyai kualitas yang sangat baik. Namun dalam proses pengalirannya air tersebut akan menerima berbagai macam bahan pencemar (sofia dkk, 2010). Beberapa tahun terakhir ini, kualitas air sungai diindonesia sebagian besar dalam kondisi tercemar, terutama setelah melewati daerah pemukiman, industri, dan pertanian (Simon dan Hidayat, (2008), menyatakan bahwa aktivitas domestik, pertanian dan industri akan mempengaruhi dan memberikan dampak terhadap kondisi kualitas air sungai terutama aktivitas domestic yang memberikan masukan konsentrasi air sungai terutaman BOD (Biological Oxygen demand) terbesar kebadan sungai (Priyambada dkk, 2008). Suatu sungai dikatakan terjadi 
penurunan kualitas air, jika air tersebut tidak dapat digunakan sesuai dengan status mutu air secara normal. Status mutu air adalah tingkat kondisi mutu air yang menunjukan kondisi cemar atau kondisi baik pada mutu air yang ditetapkan. Penentuan status mutu air dapat di lakukan salah satunya dengan menggunakan metode indeks pencemaran. Indeks pencemaran (pollution index) digunakan untuk menentukan tingkat pencemaran relatif terhadap parameter kualitas air yang diizinkan.

Kualitas air berpengaruh terhadap pertumbuhan tanaman, khususnya tanaman air. Tanaman air yang akrab kenal masyarakat dan banyakdinyakan tanaman kangkung. Baik hanya kualitas air akan mempengaruhi baik buruknya pertumbuhan tanaman air seperti kangkung. Oleh karena itu kangkung biasa digunakan untuk melihat kualitas air.Dari permasalahan Kualitas air berpengaruhi terhadap pertumbuhan tanaman Kangkung khususnya Tanaman Air diatas perlu dilakukan penelitian untuk melihat tingkat pertumbuhan tanaman kangkung terhadap pencemaran air sungai. Tujuan penelitian adalah untuk mengetahui apakah tingkat pertumbuhan tanaman kangkung bisa dijadikan indikator tingkat pencemaran air sungai dan bagaimana pertumbuhan tanaman sebagai indikator tingkat pencemaran air sungai.

\section{METODE PENELITIAN}

Jenis peneitian ini adalah penelitian kuantitatif, (Sugiono dalam Nurlily), mengatakan bahwa pendekatan kuantitatif yaitu suatu proses menemukan. Pengertian menggunakan data berupa angkah sebagai alat untuk menemukan keterangan mengenai apa yang ingin di ketahui.

Penelitian ini dilakukan pada bulan Agustus hingga bulan September 2018, bertempat di J1. KH.Ahmad Dahlan No 1 Mariyat pantai Aimas.

Bahan yang digunakan dalam penelitian ini adalah biji kangkung, tanah kering, air bersih, air kotor dan air kotor sekali. Alat yang digunakan adalah Sembilan buah pot, mister, kamera,alat tulis. Pengambiran sempel air sungai di Aimas Kabupaten Sorong yang dibagi menjadi tiga sungai yaitu : 1. Sungai Kalamono Km 23 Aimas Kabupaten Sorong yang teletak bermuarah di Daerah paling timur dari Kabupaten Sorong. 2. Sungai Campeda Jalur D KM 19 Aimas Kabupaten Sorong yang terletak bermuarah di Daerah paling timur dari Kabupaten Sorong. 3. Sungai Tuguh Merah Km 21 Aimas Kabupaten Sorong yang terletak bermuarah di Daerah paling Timur dari Kabupaten Sorong. Pengambilan sampel pada air sungai diambil secara langsung dari air sungai yang sedang mengalir, sampel ini hanya mengambarkan karakteristik pada saat pengambilan sampel. Setelah proses pengambilan sampel air pada setiap sungai yang di tentukan, masingmasing air sungai tersebut diberi label pada setiap pot, hingga bisa mengatahui air sungai yang bersih sungai kotor dan air sungai kotor sekali.

Sampel adalah sebagain dari populasi tersebut. Menurut Margono( 2010: 121). Dalam penelitian ini menggunakan sampel Benih tanaman kangkung dan Media air di Aimas Kabupaten Sorong.

Penelitian ini saya menggunakan metode eksperimen dengan menggunakan pertumbuhan tanaman kangkung . pemgambilan data berdasarkan: 1. Panjang daun pada tanaman kangkung darat 2. Lebar daun pada tanaman kangkung darat 3. Tinggi batang pada tanaman kangkung Pengambilan data dilakukan dengan mencatat hasil penelitian dan dokumentasi berupa foto.

Instrumen penelitian yang digunakan dalam penelitian ini adalah instrument untuk mengukur Pertumbuhan tanaman kangkung sebagai indikator tingkat pencemaran air sungai .

Valid atau tidaknya suatu item instrumen, dapat di ketahui dengan cara memnbandingkan pertumbuhan tanaman kangkung dengan air sungai.

Teknik Analisis Data adalah suatu metode atau cara untuk mengelola sebuah data informasi sehinggah karaktterristik data tersebut menjadi mudah untuk dipahami dan juga bermanfaat untukmenemukan solusi permasalahan, yang terutama adalah masalah yang tentang sebuah penelitian. Untuk mengetahui tingkat kualitas Pertumbuhan Tanaman Kangkung Sebagai Indikatir Pencemaran Air Sungai.

Validitas berarti alat ukur yang digunanakan dapat mengukur atau mengungkapkan hal yang seharusnya diukur atau diungkapkan (Muhammad Idrus, tingkat pencemaran air sungai di kabupaten sorong.

Hipotesis adalah jawaban sebentara terhadao rumusan masalah penelitian. Dikatakan sementara karena, jawaban yang diberikan melalui hipotesis baru didasarkan teori, dan belum menggunakan fakta. Hipotesisi mengemukakan pernyataan tentang harapan penelitian mengenai hubungan -hubungan antara valiabel - valiabel dalam persoalan.

Uji regresi linear sederhana merupakan alat uji yang digunakan untuk melihat pengaruh dari suatu valiabel. Uji regresi linear sederhana digunakan jika hanya terdapat satu variable x saja. Rumus yang digunakan untuk regresi linear sederhana adalah :

\section{$\mathrm{Y}=\mathrm{a}+\mathrm{bX}$ dimana: \\ $\mathrm{y}:$ variable y \\ a : Konstansa \\ b : Koefisien $\mathrm{x}$ \\ $\mathrm{x}$ : Variabel $\mathrm{x}$}

Uji t pada dasarnya menunjukan seberapa jauh pengaruh satu variable independen secara individual menerangkan variasi varibel terkait (Ghozali,2006). Pengujian parsial regresi dimaksudkan untuk mengetahui apakah variable bebas secara individual mempunyai pengaruh terhadap variable terkait dengan asumsi konstan. Untuk melakukan pengujian t maka rumus sebagai berikut : $\mathrm{t}=\mathrm{Bn} / \mathrm{SBn}$ dimana : 
mengikuti fungsi t dengan derajat kebebaan (df). Bn koefisien regresi masing-masing variable. $\mathrm{SBn}$; standar error masing-masing variable.

Uji F digunakan untuk mengetahui apakah variable independen secar simultan berpengruh signifikan terhadap variable dependen. Derajat kepercayaan yang digunakan adalah $5 \%$. Apa bila nilai $\mathrm{F}$ hasil perhitungan lebih besar dari nilai $\mathrm{F}$ hasil perhitungan lebig besar dari nilai $F$ table maka hipotesis alternative yang menyatakan bahwah semua variable independem secara stimulasi berpengaruh signifikan terhadap variable dependen (gunjarati 2001). $F=$ R2 N K Dimana : R2 : koefisien determinasi $\mathrm{N}$ : jumlah sampel $\mathrm{k}$ : jumlah variable bebas

\section{PEMBAHASAN}

Penelitian ini dilaksanakan di aimas unit II. Subjek pada penelitian ini adalah tanaman kangkung yang berjumlah 9 pot, yang terdiri dari 3 pot disiram mengggunakan air bersih, 3 pot disiram menggunakan air kotor dan 3 pot disiram menggunakan air kotor sekali. Proses penelitian ini dilaksanakan diantara tanggal 23 Agustus sampai tanggal 23 September 2018. Seluruh pelaksanaan pengambilan data penelitian tanaman kangkung yang diukur adalah: 1 . Panjang daun, 2. Lebar daun , 3. Tinggi Batang, 4. Warna Daun

Hasil penelitian ini diperoleh berdasarkan hasil data penelitian Tanaman kangkung yang telah dilakukan selama 1 bulan. Tanaman kangkung di siram dua kali sehari pada pukul 7:30 dan di siram sore hari pada pukul 16:30. Tabel 1. menunjukkan hasil pengukuran minggu pertama, dari hasil pengamatan dan pengukuran minggu pertama $a$ dan $b$ tanaman kangkung mengalami pertmbuhan pada masing - masing pot tanaman kangkung dan daun pada tanaman kangkung menghijau. Dapat dilihat pada tabel di bawah ini:

Tabel 1.Minggu Pertama.

\begin{tabular}{|l|l|l|l|l|}
\hline \multirow{2}{*}{$\begin{array}{l}\text { a. Minggu } \\
\text { pertama }\end{array}$} & Jumlah pengukuran & Hari pengukuran \\
\cline { 3 - 5 } & & Air bersih & Air kotor & Air kotor sekali \\
\hline 1. Panjang daun & $3 \mathrm{x}$ & 3,13 & 3,2 & 9,2 \\
\hline 2. Lebar daun & $3 \mathrm{x}$ & 0,467 & 0,467 & 0,5 \\
\hline 3. Tinggi batang & $3 \mathrm{x}$ & 1,73 & 1,33 & 2,7 \\
\hline 4. Warna daun & $3 \mathrm{x}$ & hijau & hijau & hijau \\
\hline $\begin{array}{l}\text { a. Minggu } \\
\text { pertama }\end{array}$ & \multirow{2}{*}{ Jumlah pengukuran } & Hari pengukuran & Air kotor sekali \\
\cline { 3 - 5 } 1. Panjang daun & $3 \mathrm{x}$ & Air bersih & Air kotor & 3,53 \\
\hline 2. Lebar daun & $3 \mathrm{x}$ & 3,6 & 3,63 & 0,6 \\
\hline 3. Tinggi batang & $3 \mathrm{x}$ & 0,567 & 0,567 & 4,467 \\
\hline 4. Warna daun & $3 \mathrm{x}$ & 3,167 & 3,73 & Hijau \\
\hline
\end{tabular}

Dilihat dari tabel di atas menunjukkan bahwa pertumbuhan pada panjang daun kangkung lebih subur di air kotor, Lebar daun kangkung lebih lebar di air kotor dan air bersih, tinggi kangkung lebih tinggi di air kotor sekali

Tabel 2. Pengamatan minggu ke dua

\begin{tabular}{|l|l|l|l|l|}
\hline \multirow{2}{*}{$\begin{array}{l}\text { a. Minggu } \\
\text { pertama }\end{array}$} & Jumlah pengukuran & Hari pengukuran \\
\cline { 3 - 5 } & & Air bersih & Air kotor & Air kotor sekali \\
\hline 1. Panjang daun & $3 \mathrm{x}$ & 1,967 & 2,83 & 2,6 \\
\hline 2. Lebar daun & $3 \mathrm{x}$ & 0,467 & 0,367 & 0,367 \\
\hline 3. Tinggi batang & $3 \mathrm{x}$ & 1,967 & 0,3 & 2,167 \\
\hline 4. Warna daun & $3 \mathrm{x}$ & Hijau & Hijau & Hijau \\
\hline \multirow{2}{*}{$\begin{array}{l}\text { a. Minggu } \\
\text { pertama }\end{array}$} & \multirow{2}{*}{ Jumlah pengukuran } & Hari pengukuran & \multicolumn{2}{|l|}{} \\
\cline { 3 - 5 } & & Air bersih & Air kotor & Air kotor sekali \\
\hline 1. Panjang daun & $3 \mathrm{x}$ & 1,2 & 7,2 & 1,5 \\
\hline 2. Lebar daun & $3 \mathrm{x}$ & 4,267 & 4 & 4,6 \\
\hline 3. Tinggi batang & $3 \mathrm{x}$ & Hijau & Hijau & Hijau \\
\hline 4. Warna daun & $3 \mathrm{x}$ & 1,2 & 7,2 & 1,5 \\
\hline
\end{tabular}

Tabel di atas menunjukkan bahwa pertumbuhan pada panjang daun kangkung lebih subur di air kotor, Lebar 
daun kangkung lebih lebar di air kotor dan tinggi

kangkung hijau.

kangkung lebih tinggi di air bersih dan warna daun

Tabel 3. Pengamatan minggu ke tiga

\begin{tabular}{|l|l|l|l|l|}
\hline \multirow{2}{*}{$\begin{array}{l}\text { a. Minggu } \\
\text { pertama }\end{array}$} & \multirow{2}{*}{ Jumlah pengukuran } & Hari pengukuran \\
\cline { 3 - 5 } & & Air bersih & Air kotor & Air kotor sekali \\
\hline 1. Panjang daun & $3 \mathrm{x}$ & 2,67 & 2,767 & 2,4 \\
\hline 2. Lebar daun & $3 \mathrm{x}$ & 0,4 & 0,4 & 5,1 \\
\hline 3. Tinggi batang & $3 \mathrm{x}$ & 5,4 & 4,867 & 4,67 \\
\hline 4. Warna daun & $3 \mathrm{x}$ & Hijau & Hijau & Hijau \\
\hline $\begin{array}{l}\text { a. Minggu } \\
\text { pertama }\end{array}$ & \multirow{2}{*}{ Jumlah pengukuran } & Hari pengukuran & \multicolumn{2}{l|}{} \\
\cline { 3 - 5 } & & Air bersih & Air kotor & Air kotor sekali \\
\hline 1. Panjang daun & $3 \mathrm{x}$ & 4,3 & 3.867 & 5,567 \\
\hline 2. Lebar daun & $3 \mathrm{x}$ & 6,2 & 6,67 & 8,367 \\
\hline 3. Tinggi batang & $3 \mathrm{x}$ & 5,567 & 7,03 & 9 \\
\hline 4. Warna daun & $3 \mathrm{x}$ & Hijau & Hijau & Hijau \\
\hline
\end{tabular}

Dilihat dari tabel diatas menunjukkan bahwa pertumbuhan pada panjang daun kangkung lebih subur di air kotor sekali, Lebar daun kangkung lebih lebar di air kotor sekali dan tinggi batang lebir tinggi di air kotor, masing-masing bisa dilihat pada tabel di atas.

Tabel 4.pengamatan minggu ke empat

\begin{tabular}{|l|l|l|l|l|}
\hline \multirow{2}{*}{$\begin{array}{l}\text { a. Minggu } \\
\text { pertama }\end{array}$} & Jumlah pengukuran & Hari pengukuran \\
\cline { 3 - 5 } & & Air bersih & Air kotor & Air kotor sekali \\
\hline 1. Panjang daun & $3 \mathrm{x}$ & 4,83 & 25,2 & 6,167 \\
\hline 2. Lebar daun & $3 \mathrm{x}$ & 7,267 & 9,33 & 9,5 \\
\hline 3. Tinggi batang & $3 \mathrm{x}$ & 8,8 & 9,67 & 9,8 \\
\hline 4. Warna daun & $3 \mathrm{x}$ & Hijau & Hijau & Hijau \\
\hline $\begin{array}{l}\text { a. Minggu } \\
\text { pertama }\end{array}$ & \multirow{2}{*}{ Jumlah pengukuran } & Hari pengukuran & \multicolumn{2}{l|}{} \\
\cline { 3 - 5 } 1. Panjang daun & $3 \mathrm{x}$ & Air bersih & Air kotor & Air kotor sekali \\
\hline 2. Lebar daun & $3 \mathrm{x}$ & 5,167 & 6,567 & 6,5 \\
\hline 3. Tinggi batang & $3 \mathrm{x}$ & 7,367 & 9,63 & 9,67 \\
\hline 4. Warna daun & $3 \mathrm{x}$ & 8,9 & 43,67 & 9,83 \\
\hline
\end{tabular}

Dilihat dari tabel atas menunjukkan bahwa pertumbuhan pada panjang daun kangkung lebih subur di air kotor, Lebar daun kangkung lebih lebar di air kotor sekali dan tinggi batang lebir tinggi di air kotor sekali, masing-masing bisa di lihat pada tabel di atas.

Dari semua hasil pengamatan dan pengukuran tanaman kangkung yang menunjukkan tingkat kesuburan adalah pada air yang kotor.
Hasil Perhitungan pengukuran tanaman kangkung dari minggu pertama a, b sampai minggu ke empat a, b. Deskripsi hasil penelitian tersebut disajikan dalam bentuk distribusi frekuensi, di mana data yang digunakan untuk membuat tabel distribusi frekuensi bergolong adalah hasil data pretest. Deskripsi hasil pengamatan tanaman kangkung dapat di deskripsi kan sebagai berikut:

Tabel 6. Diskripsi hasil pengamatan tanaman kangkung

\begin{tabular}{|l|l|l|l|l|l|}
\hline \multirow{2}{*}{$\begin{array}{l}\text { Minggu 1 } \\
\text { sampae 4 }\end{array}$} & \multirow{2}{*}{$\begin{array}{l}\text { Jumlah } \\
\text { pengukuran }\end{array}$} & Hari pengukuran & \multirow{2}{*}{ Hasil akhir } \\
\cline { 2 - 5 } & Air bersih & Air kotor & Air kotor sekali & \\
\hline$\square$ Panjang daun & $24 \mathrm{x}$ & 29,664 & 52,261 & 39,464 & 40,464 \\
\hline$\square$ Lebar daun & $24 \mathrm{x}$ & 23,935 & 34,631 & 35,604 & 31,39 \\
\hline$\square$ Tinggi batang & $24 \mathrm{x}$ & 39,798 & 74,579 & 47,234 & 53,870 \\
\hline$\square$ Warna daun & Hijau & Hijau & Hijau & Hijau \\
\hline
\end{tabular}


Dari hasil statistik distribusi frekuensi pada tabel di atas menunjukkan bahwa panjang daun, lebar daun dan tinggi batang memiliki nilai yang valid.

Penelitian ini bertujuan untuk mengetahui pertumbuhan tanaman kangkung.Hipotesis penelitian ini yaitu "ada pengaruh yang signifikan terhadap pertumbuhan tanaman kangkung sebagai indikantor tingkat pencemaran air sungai".

Data penelitian ini bersifat normal dan homogen sehingga analisis data yang digunakan untuk menguji hipotesis tersebut adalah uji $\mathrm{t}$ (t-test) tepatnya menggunakan One-Sample T-Test. Pengujian hipotesi menggunakan aplikasi IBM SPSSStatistics 20 for Windows. Data bersifat signifikan apabila nilai $\mathrm{p}<$ 0.05 .

Berdasarkan perhitungan data tersebut diperoleh nilai thitung $(3,264)>\operatorname{ttabel}(3,182)$ dan $P(0,005)<\alpha$ $(0,05)$. Hasil tersebut menunjukkan bahwa nilai thitung lebih besar dari pada ttabel dan probabilitas signifikansi kurang dari 0,05 maka Ha: diterima dan Ho: ditolak. Jika Ha diterima maka hipotesisnya berbunyi "Ada pengaruh yang signifikan terhadap tanaman kangkung sebagai indikator tingkat pencemaran air sungai.

Proses penelitian tanamankangkung sebagai indikator tingkat pencemaran air yang berjumlah 9 pot, terdiri dari 3 pot disiram mengggunakan air bersih, 3 pot disiram menggunakan air kotor dan 3 pot disiram menggunakan air kotor sekali. Proses penelitian ini dilaksanakan diantara tanggal 23 Agustus sampai tanggal 23 September 2018. Seluruh pelaksanaan pengambilan data penelitian tanaman kangkung yang di ukur adalahPanjang daun, lebar daun, tinggi batang, warna daun.Penelitian telah dilakukan selama 1 bulan. Tanaman kangkung di siram dua kali sehari pada pukul 7:30 dan di siram soreh hari pada pukul 16:30.

Berdasarkan hasil analisis data diperoleh nilai thitung $(3,264)>\mathrm{t}$ tabel $(3,182)$ dan $(0,005)>\alpha$ $(0,05)$. Hasil tersebut menunjukkan bahwa nilai $t$ hitung lebih besar dari pada ttabel dan probabilitas signifikansi kurang dari 0,05. Hasil anlisis tersebut menunjukkan bahwa adapengaruh yang signifikan pertumbuhan tanaman kangkung sebagai indikantor tingkat pencemaran air sungai sungai. S.J. Iswarin (2011) Perubahan Potensial Membran Sel Akar Kangkung Sebagai Indikator Pencemaran Lingkungan Air Limbah. Penelitian terdahulu memiliki tentang tinggi tanaman,jumlah daun, panjang daun diameter batang,panjng akar berat basah,berat kering dan pengukuran kondisi abiotic meliputi $\mathrm{pH}$ media tanaman, sedangkan penelitian yang saya lakukan untuk mengukur panjng daun,lebar daun dan tinggi batang tanaman kangkung yang disiram dengan air sungai bersih, kotor, dan kotor sekali.

\section{KESIMPULAN}

Berdasarkan Penelitian data tersebut diperoleh nilai thitung $(3,264)>$ ttabel $(3,182)$ dan $P(0,005)<\alpha$ $(0,05)$. Hasil tersebut menunjukkan bahwa nilai thitung lebih besar dari pada ttabel dan probabilitas signifikansi kurang dari 0,05 maka Ha: diterima dan Ho: ditolak. Jika Ha diterima maka hipotesisnya berbunyi "Ada pengaruh yang signifikan terhadap tanaman kangkung sebagai 30ndicator tingkat pencemaran air sungai.

\section{DAFTAR PUSTAKA}

Badan Lingkungan Hidup Kabupaten Kearanganyar. 2010.

Laporan Pementauan Kualitas Air Sungai Kabupaten Karanganyar Tahun 2010.

BadanPusatStatistik 2001,KaranganyarDalamAngkat 2010.

Bahtiar. Ayi 2007. Polusi Air Tanah Akibat Limbah Industri Dan Rumah Tanggah Masyarakat tentang Konservasi Air Tanah di Wilayah Rancaekek Kabupaten Bandung.

BLH Provinsi Bali, 2009. Status Lingkungan Hidup Daerah Pr Hadi, A. 2007.

Badan Litbang Pertanian. 2012. Pengembangan kawasan rumah pangan lestari (KRPL). Badan Penelitian dan Pengembangan Pertanian.

BBP2TP, 2011. Petunjuk pelaksanaan pengembangan model kawasan rumah pangan lestari.

BBP2TP, Badan Badan Penelitian dan Pengembangan Pertanian Kementerian Pertanian Dinas Lingkungan Hidup Kabupaten Kearanganyar 2008.

Laporan Akhir Pemantauan Kualitas Air Sungai Kabupaten Karanganyar Tahun 2008.

Dhkhikah, Y dan Koesoemawati , D.J. 2007. Studi Ketersedian prasaran Air Bersih dan Sanitasi di Permukiman pada Kota Jember. Jurnal Purifikasi,Vol.8,No.2, Desember 2007 : 163-168. Daut. Toksikologi Lingkungan, CV.

Healthy and Sanitation, Makasar 2008. Dinas Pertanian Kota Jambi, 2010. Laporantahunan. DinasPertanian Kota Jambi. Provinsi Jambi.

Hadi, A. 2007. Prinsip Pengelolaan Pengambilan Sampel Lingkungan. Penerbit PT. Gramedia. Jakarta.

Haryoto, 2009. Kreatif di seputar rumah bertanam kangkung raksasa di pekarangan. Penerbit Kanisius. Prinsip pengelolaan Pengambilan Sampel Lingkungan. PenerbitPT. Gramedia. Jakarta. Palar,

Heryando. Pencemarandan Toksikologi LogamBerat. Jakarta:RinekaCipta 200 